\title{
Behcet's Disease in an Adult Male From Nepal: A Case Report
}

\author{
Madan Basnet ${ }^{1}$, Abisha Phudong ${ }^{2}$, Kamal Gautam ${ }^{3}$, Bishnu Pathak ${ }^{4}$, Suman Gaire ${ }^{5}$, \\ Narayan Bohara ${ }^{6}$, and Ayushi Srivastava ${ }^{7}$ \\ ${ }^{1}$ Tribhuvan University Teaching Hospital \\ ${ }^{2}$ Nepalese Army Institute of Health Sciences \\ ${ }^{3}$ Patan Academy of Health Sciences \\ ${ }^{4}$ Shree Birendra Hospital \\ ${ }^{5}$ Palpa hospital \\ ${ }^{6}$ Oxford University Clinical Research Unit \\ ${ }^{7}$ Norvic International Hospital
}

August 6, 2021

\begin{abstract}
Behcet's Disease is a rare systemic vasculitis characterized by recurrent episodes of acute inflammation affecting blood vessels of all sizes. Symptoms include orogenital apthosis, cutaneous skin lesions, and uveitis. We present the case of a 38-year-old Nepalese man with Behcet's Disease. In Nepal, Behcet's Disease may still be under-reported.
\end{abstract}

\section{Behcet's Disease in an Adult Male From Nepal: A Case Report}

Madan Basnet ${ }^{1}$ Kamal Gautam ${ }^{2}$ Bishnu Deep Pathak ${ }^{3}$ Abisha Phudong ${ }^{4}$ Suman Gaire ${ }^{5}$ Narayan Bohora ${ }^{2}$ Ayushi Srivastava ${ }^{6}$

${ }^{1}$ Tribhuvan University Teaching Hospital, Maharajgunj, Kathmandu, Nepal, 44600

${ }^{2}$ Patan Academy of Health Sciences, Oxford University Clinical Research Unit, Lalitpur, 44700

${ }^{3}$ Department of Medicine, Shree Birendra Hospital, Chhauni

${ }^{4}$ Nepalese Army Institute of Health Sciences, Bhandarkhal, Kathmandu, 44600

${ }^{5}$ Palpa hospital, Department of emergency medicine, Palpa, Tansen, NP

${ }^{6}$ Norvic International Hospital, Thapathali, Kathmandu, Nepal, 44600

\section{Corresponding author}

Madan Basnet

Tribhuvan University Teaching Hospital,(Medical Officer)

Institute of Medicine, Tribhuvan University

Maharajgunj, 44600, Nepal

Email: madanbasnet381138@gmail.com

\section{Abstract}


Behcet's Disease is a rare systemic vasculitis characterized by recurrent episodes of acute inflammation affecting blood vessels of all sizes. Symptoms include orogenital apthosis, cutaneous skin lesions, and uveitis. We present the case of a 38-year-old Nepalese man with Behcet's Disease. In Nepal, Behcet's Disease may still be under-reported.

\section{Key clinical message}

This case report highlights considering Behcet's disease as a diagnosis in orogenital ulcers and uveitis, although its prevalence is unknown in Nepal due to underreporting. Also, collaboration for patient care among relevant specialties is required.

\section{Keywords}

Behcet's Disease, Behcet disease, Behcet's Syndrome, Nepal, orogenital ulcer

\section{Introduction}

Behcet's Disease is a rare systemic vasculitis with relapsing and remitting episodes of acute inflammation involving all sizes and types of vessels, with more involvement of veins more than arteries(1). It usually presents with orogenital apthosis, cutaneous skin lesions, hypopyon, and uveitis(2,3). But frequent involvement of the articular system, central nervous system, and gastrointestinal tracts has also been reported(4). The usual age of onset is on their third decades of life, and males are more severely affected than females(1). The disease is more prevalent in Turkish, Mediterranean, Middle East regions, sometimes referred to as the Silk Road disease(5). It is less frequent in other parts of the world, including the Indian subcontinent(6). The disease is a rare presentation in Nepal, and its prevalence in Nepal is yet to be determined(4). Here we present a case of a 38-year-old male from Nepal with features of Behçet's syndrome.

\section{Case Report}

About one and a half years ago, a 38-year-old married male Nepalese serving soldier presented to our center with complaints of diminution of vision of the left eye for three days. His visual acuities were 6/24 in OS (Oculus Sinister) and 6/6 in OD (Oculus Dextrus). Intraocular pressure (IOP) was 13 and 12 in OS and OD, respectively. On ophthalmological examination of the left eye, $4+$ cells, $2+$ flare, blue dot cataract, $3+$ vitreous cells, and snow banks were noted. In addition, there were multiple lesions with arteritis in the fundus. The findings of the right eye were unremarkable. There were no abnormalities on systemic examination. With the diagnosis of uveitis (anterior and intermediate), the patient was prescribed prednisolone and atropine eye drops.

On further inquiry, he had a history of recurrent episodes of oral ulceration for several months that was aggravated for the last one week. His past medical history revealed the episodic occurrence of genital ulcers a few years back. So, for detailed evaluation, the patient was referred to Dermatology outpatient department (OPD), where a panel of investigations was sent. His routine blood investigations were normal.

Differential diagnoses included aphthous ulcer, secondary syphilis, oro-mucosal lichen planus, psoriasis vulgaris, systemic lupus erythematosus, and Behcet's Disease. To rule out these differential diagnoses, further investigations were sent. VDRL, TPHA, ANA, Anti DS DNA, HLA B27, and HLA B25 came out to be negative. However, he was positive for HLA B51.

Pathergy test was done, which showed a positive result. According to International Criteria for Behcet Disease (ICBD) criteria, all these features were diagnostic of Behcet disease. The patient was then started on oral Methotrexate $15 \mathrm{mg}$ once a week along with oral folic acid $5 \mathrm{mg}$ once weekly. Likewise, the oral ulcer was symptomatically treated with oral saline gargle, quadrajel(Lidocaine, Chlorhexidine Gluconate, and Metronidazole), oroheal gel(Triamcinolone Acetonide $0.1 \% \mathrm{w} / \mathrm{w})$, zinc, and vitamin C supplements. Since the diagnosis, the patient has been on follow-up regularly with different complaints at different times, as mentioned in table 1. 


\begin{tabular}{|c|c|c|c|}
\hline DATE & COMPLAINTS & ASSESSMENT & MANAGEMENT \\
\hline $2020 / 02 / 23$ & $\begin{array}{l}\text { Floaters in left eye for } \\
3-4 \text { days }\end{array}$ & $\begin{array}{l}\text { Panuveitis in OS IOP: } 18 \\
\text { in OD and } 47 \text { in OS }\end{array}$ & $\begin{array}{l}\text { Dorzolamide and Timolol } \\
\text { eye drops Advised for } \\
\text { light-duty and no } \\
\text { paper/computer works }\end{array}$ \\
\hline 2020/03/01 & $\begin{array}{l}\text { Dizziness and left-sided } \\
\text { headache }\end{array}$ & $\begin{array}{l}\text { Visual acuity: } 6 / 6 \text { in OD } \\
\text { and } 6 / 24 \text { in OS IOP: } 12 \\
\text { in OD and } 13 \text { in OS }\end{array}$ & Analgesics SOS \\
\hline 2020/03/06 & $\begin{array}{l}\text { Headache left-sided } \\
\text { aggravated }\end{array}$ & $\begin{array}{l}\text { Visual acuity: } 6 / 6 \text { in OD } \\
\text { and } 6 / 36 \text { in OS IOP: } 19 \\
\text { in OD and } 18 \text { in OS }\end{array}$ & $\begin{array}{l}\text { Analgesics SOS Advised } \\
\text { for light-duty, no } \\
\text { paper/computer works }\end{array}$ \\
\hline $2020 / 03 / 20$ & $\begin{array}{l}\text { Pricking sensation of } \\
\text { bilateral eyes Redness of } \\
\text { eyes (left }>\text { right) }\end{array}$ & $\begin{array}{l}\text { Mild superficial } \\
\text { conjunctival congestion }\end{array}$ & $\begin{array}{l}\text { Antibiotic eye drops Eye } \\
\text { lubricants Advised to } \\
\text { avoid paper/computer } \\
\text { works }\end{array}$ \\
\hline 2020/03/22 & $\begin{array}{l}\text { Generalized body } \\
\text { weakness Backache } \\
\text { Tingling sensation }\end{array}$ & $\begin{array}{l}\text { Orthopedic examination } \\
\text { showed normal }\end{array}$ & $\begin{array}{l}\text { Analgesics SOS } \\
\text { Diclofenac gel } \\
\text { Cyanocobalamin tablets }\end{array}$ \\
\hline 2020/04/02 & $\begin{array}{l}\text { Scalp pruritus New Oral } \\
\text { lesions Pain over bilateral } \\
\text { groins }\end{array}$ & $\begin{array}{l}\text { Multiple scalp folliculitis } \\
\text { Oral ulcers }\end{array}$ & $\begin{array}{l}\text { Quadrajel Normal saline } \\
\text { mouth wash Analgesics } \\
\text { SOS }\end{array}$ \\
\hline $2020 / 04 / 28$ & $\begin{array}{l}\text { Pain and numbness over } \\
\text { the left half of the body }\end{array}$ & $\begin{array}{l}\text { Neurological } \\
\text { examination: } \\
\text { Unremarkable }\end{array}$ & $\begin{array}{l}\text { Oral Pregabalin Oral } \\
\text { Buscopan }\end{array}$ \\
\hline 2020/05/06 & $\begin{array}{l}\text { Eyeball pain and } \\
\text { photophobia New Oral } \\
\text { and genital lesions Pain } \\
\text { and numbness over the } \\
\text { left half of the body }\end{array}$ & $\begin{array}{l}\text { IOP: } 15 \text { in OD and } 14 \text { in } \\
\text { OS Multiple skin } \\
\text { folliculitis over genital } \\
\text { area and scalp Oral ulcers }\end{array}$ & $\begin{array}{l}\text { Oral Methylprednisolone } \\
16 \text { mg twice a week for } 4 \\
\text { weeks Fusidic acid cream } \\
2 \% \text { Ketoconazole } \\
\text { shampoo }\end{array}$ \\
\hline 2020/06/03 & $\begin{array}{l}\text { Left-sided temporal and } \\
\text { parietal headache }\end{array}$ & Unremarkable & Analgesics Counseling \\
\hline $2020 / 06 / 25$ & $\begin{array}{l}\text { Headache Tingling } \\
\text { sensation of the left side } \\
\text { of the body }\end{array}$ & Unremarkable & $\begin{array}{l}\text { Oral Cyanocobalmin } \\
\text { Analgesics Counseling }\end{array}$ \\
\hline 2020/08/24 & $\begin{array}{l}\text { Left eye pain aggravated } \\
\text { on bending down } \\
\text { Headache Palpitations } \\
\text { Left-sided weakness }\end{array}$ & $\begin{array}{l}\text { IOP: } 16 \text { in OD and } 32 \text { in } \\
\text { OS Blood Pressure: } \\
\text { 140/90 } \mathrm{mm} \text { of } \mathrm{Hg}\end{array}$ & $\begin{array}{l}\text { Timolol eye drops } \\
\text { Dorzolamide eye drops } \\
\text { Oral Acetazolamide } \\
\text { Advised for regular } \\
\text { monitoring of IOP }\end{array}$ \\
\hline 2020/09/30 & Facial lesions & $\begin{array}{l}\text { Multiple papular } \\
\text { eruptions over the face }\end{array}$ & Clindamycin gel \\
\hline 2020/12/13 & Low back pain & Unremarkable & Analgesics Counseling \\
\hline 2020/12/13 & $\begin{array}{l}\text { Blurring of vision of the } \\
\text { left eye }\end{array}$ & Intermediate uveitis & $\begin{array}{l}\text { Oral Prednisolone } 50 \mathrm{mg} \\
\text { PO once daily for one } \\
\text { week }\end{array}$ \\
\hline 2021/01/05 & New oral lesion & $\begin{array}{l}\text { Multiple oral ulcers over } \\
\text { the erythematous base }\end{array}$ & $\begin{array}{l}\text { Topical quadrajel Oral } \\
\text { gargle }\end{array}$ \\
\hline
\end{tabular}




\begin{tabular}{llll}
\hline DATE & COMPLAINTS & ASSESSMENT & MANAGEMENT \\
\hline $2021 / 04 / 20$ & $\begin{array}{l}\text { Pricking sensation of the } \\
\text { left eye Headache over } \\
\text { left frontal and temporal } \\
\text { regions }\end{array}$ & $\begin{array}{l}\text { VA: 6/6 in OD and 6/6 } \\
\text { in OS: 12 in OD and }\end{array}$ & $\begin{array}{l}\text { Fluorometholone eye } \\
\text { drops Combigan } \\
\text { (brimonidine tartrate }\end{array}$ \\
& & & $0.2 \%$ and timolol \\
& & $0.5 \%$ )eye drops Eye \\
lew eruptions over & Skin folliculitis & lubricants \\
& genital areas & & \\
\hline
\end{tabular}

On 2021/06/25, the patient presented with complaints of right-sided chest pain, headache, and dizziness. Vitals were within normal limits. General and systemic examinations were unremarkable. Baseline investigations, including complete blood count, renal function test, liver function test, serum electrolytes, urine routine and microscopic, and chest X-ray, showed normal findings. Creatinine phosphokinase (CPK-MB) was $18 \mathrm{IU} / \mathrm{L}$, and Troponin-I was negative. C - reactive protein was positive $(63.18 \mathrm{mg} / \mathrm{L})$, and Erythrocyte Sedimentation Rate was $40 \mathrm{~mm} / \mathrm{hr}$, possibly indicating the active stage of the disease. After that, a NonContrast CT head and High-Resolution CT chest were done, which were normal. Ear, Nose, and Throat (ENT) consultation was done for dizziness, but they suggested no possible middle ear causes. His headache was associated with throbbing eyeball pain. On ophthalmologic consultation, peripheral choroiditis and vitritis were noted with normal intraocular pressure and visual acuity. Oral prednisolone $50 \mathrm{mg}$ once daily was started and tapered over several days. Likewise, atropine and prednisolone eye drops were also prescribed. During the hospital stay, the visual acuity deteriorated, and IOP also increased. Oral acetazolamide was started, and IOP gradually decreased to the normal range. Visual acuity was not significantly improved till discharge.

The patient also developed pain and tingling sensation over the left half of the head, face, and neck. In between, he was referred to a rheumatologist, who recommended the use of adalimumab. Sputum smear for acid-fast bacilli, Mantoux test, and chest X-ray were done to rule out tuberculosis. Similarly, liver function tests, viral markers, and ultrasound abdomen were performed to rule out viral hepatitis. Finally, the first and second dose of adalimumab 40mg subcutaneously on an interval of fifteen days was administered, and the patient was discharged and advised to follow up after two weeks. His ocular symptoms have improved on follow-up examination.

\section{Discussion}

Behcet's disease (BD) is a rare, systemic disorder initially described by Hulusi Behcet, a Turkish dermatologist, as a triad of uveitis and recurrent oral and genital ulcers. It is prevalent in people of Mediterranean and Middle East countries and less frequent in the Indian subcontinent. The disease usually manifests during the 3 rd and 4 th decade of their life with male predominance $(7,8)$. We present a case report of a male serving soldier from Nepal in his fourth decade of life. Testosterone may play a role in neutrophil and Th-1 cell activation. This could explain why male patients have a more severe case of $\operatorname{BD}(9)$.

The disease raises the mortality rate, particularly in young male patients. Large vessel involvement (pulmonary artery aneurysm), neurological involvement, gastrointestinal system involvement, and cardiac involvement are the most common causes of mortality(10). The exact cause of Behcet's Disease is unknown and is thought to be multifactorial. The MHC class I region, which includes HLA-B*51, contains the strongest genetic risk factor for BD. There is a 5. 78-fold higher chance of getting BD for individuals with the HLA-B*51/B5 allele than those who did not have this gene (11). Other potential factors can be microbial factors as oral aphthous ulcer typically precede the systemic presentations and occurs before every recurrence of the disease. This case was positive for HLA-B51, which demonstrated probable genetic cause for the occurrence of the disease. Although the significance of HLA-B*51 is well established, it is found to 
be positive in roughly $60 \%$ of patients with Bechet disease. HLA-B*51's role in the genetic predisposition to the Behcet disease is around $12-19 \%$ (12).

There is no confirmatory test for diagnosing Behcet's Disease as the history and clinical picture are often sufficient for the diagnosis. However, diagnostic criteria proposed by an International Study Group are used for research purposes and clinical purposes too. According to International Study Group criteria for Behcet's Disease (13), there must be Recurrent oral ulcerations (Minor aphthous, major aphthous, or herpetiform ulcerations which recurred at least 3 times in 12 month period). In addition, two of the following criteria must be met: Recurrent genital Ulcerations, Eye lesions( Uveitis, cells in vitreous on slit-lamp examination, or retinal vasculitis), Skin lesions (Erythema nodosum, pseudofolliculitis, papulopustular lesions), and Positive Pathergy test.

The International Criteria for Behcet's Disease(ICBD)(14) are proposed to assist earlier diagnosis as ISG clinical diagnosis has low sensitivity. According to signs and symptoms, the International Criteria for Behcet's Disease has a scoring system; 2 points each for ocular lesions, genital apthosis, and oral apthosis. Each point for skin lesions, neurological manifestations, and vascular manifestations, and Positive pathergy test. A score of more than or equals to 4 indicates Behcet's diagnosis. Our patient had ocular lesions, genital apthosis, oral apthosis, skin lesions, vascular manifestations ( fundal arteritis), and a positive pathergy test; hence ICBD score was calculated to be 8 , which is strongly suggestive of Behcet's Disease.

BD responds well to steroids. When vital organs are affected, a combination of corticosteroids and immunosuppressant medications is recommended. Our patient responded very well to the steroids. Due to relapsing ocular symptoms, he was placed on adalimumab (TNF- $\alpha$ antagonist). TNF- $\alpha$, a pro-inflammatory cytokine, is involved in the autoimmune response, inflammation induction, and maintenance. Therefore, it becomes a crucial target molecule in the disease's treatment(15).

Adalimumab was linked to a reduced risk of uveitis aggravation or visual impairment in non-infectious active intermediate, posterior uveitis, and panuveitis in a placebo-controlled phase 3 research involving patients with $\mathrm{BD}(16)$.

\section{Conclusions}

The prevalence of Behcet's Disease is unknown in Nepal and the Indian subcontinent. Despite that, it should be considered a differential diagnosis in recurrent oro-genital ulcers, as Behcet's Disease may still be under-reported in Nepal. Earlier diagnosis will help delay the progression of the disease and prevent other complications. Regular follow-up and proper care of BD are required because of the high frequency of vital organ involvement. Collaboration among relevant specialties such as dermatologist, ophthalmologist, internal medicine, neurologist, dentist, rheumatologist is required to improve patient outcomes due to its multisystemic nature.

\section{Consent}

Written informed consent was obtained from the patient to publish the case report.

\section{Acknowledgement}

None

\section{Conflict of interest}

Authors have no conflicts of interest to declare

\section{Authors' contribution}

Madan Basnet and Kamal Gautam wrote the original manuscript. Suman Gaire, Narayan Bohora, and Ayushi Srivastava reviewed and edited the original manuscript. Bishnu Deep Pathak and Abisha Phudong were involved in the management of the case, reviewed and edited the manuscript.

\section{Data availability statement}


All the necessary data are available in the article itself.

\section{Funding}

No funding was received for the study.

\section{References}

1. Seyahi E, Yurdakul S. Behçet's Syndrome and Thrombosis. Mediterr J Hematol Infect Dis. 2011;3(1):e2011026.

2. Verity DH. Behcet's disease: from Hippocrates to the third millennium. Br J Ophthalmol. 2003 Sep $1 ; 87(9): 1175-83$.

3. Zeidan MJ, Saadoun D, Garrido M, Klatzmann D, Six A, Cacoub P. Behçet's disease physiopathology: a contemporary review. Autoimmun Highlights. 2016 Dec;7(1):4.

4. Paudyal B, Gyawalee M, Manandhar A, Sigdel keshav raj. Behçet's Disease: An Account of Three Cases. J Nepal Health Res Counc. 2012 Sep 1;10:250-3.

5. Alpsoy E. Behçet's disease: A comprehensive review with a focus on epidemiology, etiology and clinical features, and management of mucocutaneous lesions. J Dermatol. 2016 Jun;43(6):620-32.

6. Pande I, Uppal SS, Kailash S, Kumar A, Malavtya AN. BEHÇET'S DISEASE IN INDIA: A CLINICAL, IMMUNOLOGICAL, IMMUNOGENETIC AND OUTCOME STUDY. Rheumatology. 1995;34(9):825-30.

7. Yazici H, Fresko I, Yurdakul S. Behçet's syndrome: disease manifestations, management, and advances in treatment. Nat Clin Pract Rheumatol. 2007 Mar;3(3):148-55.

8. Sachdev N, Kapali N, Singh R, Gupta V, Gupta A. Spectrum of Behçet's disease in the Indian population. Int Ophthalmol. 2009 Dec;29(6):495-501.

9. Yavuz S, Akdeniz T, Hancer V, Bicakcigil M, Can M, Yanikkaya-Demirel G. Dual effects of testosterone in Behcet's disease: implications for a role in disease pathogenesis. Genes Immun. 2016 Sep;17(6):335-41.

10. Yazici H, Esen F. Mortality in Behçet's syndrome. Clin Exp Rheumatol. 2008 Oct;26(5 Suppl 51):S138140.

11. de Menthon M, LaValley MP, Maldini C, Guillevin L, Mahr A.HLA-B51/B5 and the risk of Behçet's disease: A systematic review and meta-analysis of case-control genetic association studies. Arthritis Rheum. 2009 Oct 15;61(10):1287-96.

12. Gül A. Genetics of Behçet's disease: lessons learned from genomewide association studies. Curr Opin Rheumatol. 2014 Jan;26(1):56-63.

13. Internationalstudygroupforbehc. Criteria for diagnosis of Behcet's disease. The Lancet [Internet]. 1990 May [cited 2021 Jul 27];335(8697). Available from: https://linkinghub.elsevier.com/retrieve/pii/014067369092643V

14. International Team for the Revision of the International Criteria for Behçet's Disease (ITR-ICBD), Davatchi F, Assaad-Khalil S, Calamia KT, Crook JE, Sadeghi-Abdollahi B, et al. The International Criteria for Behçet's Disease (ICBD): a collaborative study of 27 countries on the sensitivity and specificity of the new criteria. J Eur Acad Dermatol Venereol. 2014 Mar;28(3):338-47.

15. Lee YJ, Horie Y, Wallace GR, Choi YS, Park JA, Choi JY, et al. Genome-wide association study identifies GIMAP as a novel susceptibility locus for Behçet's disease. Ann Rheum Dis. 2013 Sep;72(9):1510-6.

16. Jaffe GJ, Dick AD, Brézin AP, Nguyen QD, Thorne JE, Kestelyn P, et al. Adalimumab in Patients with Active Noninfectious Uveitis. N Engl J Med. 2016 Sep 8;375(10):932-43. 